medRxiv preprint doi: https://doi.org/10.1101/2021.01.13.21249429; this version posted May 27, 2021. The copyright holder for this preprint (which was not certified by peer review) is the author/funder, who has granted medRxiv a license to display the preprint in perpetuity.

\title{
Elevated Angiopoietin-2 inhibits thrombomodulin-mediated anticoagulation in critically ill COVID-19 patients
}

*Corresponding author: Marie Jeansson, marie.jeansson@ki.se

Competing interests: The authors have declared that no conflict of interest exists

\begin{abstract}
Several studies suggest that hypercoagulation and endothelial dysfunction play central roles in severe forms of COVID-19 infections. We hypothesized that the high levels of the inflammatory cytokine Angiopoietin-2 (ANGPT2) reported in hospitalized COVID-19 patients might promote hypercoagulation through ANGPT2 binding to thrombomodulin with resulting inhibition of thrombin/thrombomodulin-mediated physiological anticoagulation. Plasma was collected from critically ill COVID-19 patients treated in the intensive care unit (ICU) at Uppsala University Hospital and ANGPT2 was measured at admission (61 patients) and after ten days (40 patients). ANGPT2 levels were compared with biochemical parameters, clinical outcome, and survival. We found that ANGPT2 levels were increased in COVID-19 patients in correlation with disease severity, hypercoagulation, and mortality. To test causality, we administered ANGPT2 to wildtype mice and found that it shortened bleeding time in a tail injury model. In further support of a role for ANGPT2 in physiological coagulation, bleeding time was increased in endothelial-specific Angpt2 knockout mice. Using in vitro assays, we found that ANGPT2 inhibited thrombomodulin-mediated anticoagulation and protein $\mathrm{C}$ activation in human donor plasma. Our data reveal a novel mechanism for ANGPT2 in hypercoagulation and suggest that Angiopoietin-2 inhibition may be tested in the treatment of hypercoagulation in severe COVID-19 infection.
\end{abstract}


medRxiv preprint doi: https://doi.org/10.1101/2021.01.13.21249429; this version posted May 27, 2021. The copyright holder for this preprint (which was not certified by peer review) is the author/funder, who has granted medRxiv a license to display the preprint in perpetuity.

\section{Introduction}

SARS-CoV-2 infection may be paucisymptomatic or lead to coronavirus disease-2019 (COVID-19), which has a wide range of symptoms and may cause severe illness, in particular in individuals with other cardiovascular risk factors (1). Thrombotic and thromboembolic disease have emerged as major COVID-19 complication despite routine thrombosis prophylaxis being standard of care (2-5). Microthrombosis has been suggested to contribute to both respiratory failure and neurological complications $(6,7)$, and activation of the coagulation system indicates a poor prognosis among COVID-19 patients in intensive care $(1,7-9)$.

Angiopoietin-2 (ANGPT2) is an inflammatory cytokine, the circulatory level of which correlates with adverse outcomes in several critical care syndromes, including acute respiratory disease syndrome (ARDS) and sepsis (reviewed in (10)). Elevated plasma ANGPT2 is a strong predictor of death in infection-mediated ARDS independent of the infectious agent (11), and elevated plasma ANGPT2 is further associated with disseminated intravascular coagulation (DIC) in conjunction with sepsis (12). In COVID-19, recent data show that the ANGPT2 level is a good predictor of ICU admission (13) and correlates with the severity of disease $(14,15)$.

ANGPT2 exerts its effects through different molecular mechanisms, the most well-studied being inhibition of Tie2 receptor signaling. This causes destabilization of the endothelium in most vascular beds and promotes inflammation, vascular leakage, impairment of the endothelial glycocalyx, and activation of $\alpha 5 \beta 1$ integrin signaling (16-26). The administration of Tie2 activating agents confers vascular protection and reduced mortality in experimental models of sepsis $(12,27,28)$. Moreover, the recent discovery that ANGPT2 binds thrombomodulin (29) suggest that ANGPT2 may have additional and direct effects on the coagulation system. Thrombomodulin is constitutively expressed on the luminal surface of endothelial cells, where it is an important member of the intrinsic anticoagulant pathway and also an anti-inflammatory agent (30). Thrombomodulin inhibits the procoagulant functions of thrombin by binding and inhibiting its interaction with procoagulant substrates and instead promoting thrombincatalyzed activation of protein C (APC) (31). Endothelial-specific knockout of thrombomodulin in mice disrupts APC formation and causes lethal thrombus formation (32), highlighting the potency of this pathway.

We hypothesized that the increased plasma levels of ANGPT2 observed in COVID-19 patients could contribute to hypercoagulation by inhibition of thrombomodulin-mediated activation of protein C. To investigate this, we measured plasma ANGPT2 and coagulation parameters in relation to clinical outcome in a cohort of critically ill COVID-19 patients and healthy blood donor controls. We further utilized experimental animals and in vitro assays to investigate if ANGPT2 could inhibit thrombomodulin-mediated anticoagulation and activation of protein C. 
medRxiv preprint doi: https://doi.org/10.1101/2021.01.13.21249429; this version posted May 27, 2021. The copyright holder for this preprint (which was not certified by peer review) is the author/funder, who has granted medRxiv a license to display the preprint in perpetuity.

\section{Results}

\section{COVID-19 patients admitted to the ICU}

The study included a cohort of 61 patients admitted to the ICU at Uppsala University Hospital due to SARS-CoV-2 infection. Plasma samples were collected 1-4 days after admission and after 10-14 days for 40 patients with extended length of stay at the ICU. Plasma from 40 blood donors for the hospital blood bank were used as controls to generate normal ranges for ANGPT2, ANGPT1, VWF, and ADAMTS13. Patient demographic characteristics are summarized in Table 1.

\section{ANGPT2 is elevated in critically ill COVID-19 patients}

Assessment of plasma ANGPT2 concentrations revealed that ANGPT2 was significantly elevated $(\mathrm{p}<0.0001)$ in patients at ICU admission compared to controls (Table 2). At 10-14 days after admission, ANGPT2 was further increased $(\mathrm{p}<0.01)$ (Table 2). ANGPT2 levels were further analyzed with regards to survival. ANGPT2 was significantly higher, both at admission and at 10-14 days, in non-recovering patients compared to recovering patients $(p<0.01$ and $\mathrm{p}<0.001$, respectively) (Figure 1A). We then further analyzed ANGPT2 and survival by using Kaplan-Meier plots (Figure 1B, C). Using the optimal cut-off value of $8.3 \mathrm{ng} / \mathrm{ml}$ for ANGPT2 (please refer to Statistics for details), we demonstrated that ANGPT2 level at admission was strongly predictive of death $(\mathrm{p}<0.0001)$ but also at the later time point $(\mathrm{p}<0.0001)$ in the studied cohort. Plasma concentrations of the Tie2 agonist ANGPT1 were minimally affected (Figure 1D). Other clinical and measured parameters of the patients during their ICU stay are summarized in Table 2.

Further analysis showed that ANGPT2 correlated with several markers of disease severity, shown in a heatmap representing the degree of correlation ( $r$ ) (Figure 1E), with values and significance in Suppl. Table 1. The simplified acute physiology (SAPS-3) score (probability of death) correlated significantly with ANGPT2 at ICU admission $(p<0.05)$ (Table 3). Sequential organ failure assessment (SOFA) score was calculated for the same days as collection of plasma samples. The SOFA score represents six organ systems, were each organ system is assigned a point value from 0 (normal) to 4 (high degree of dysfunction/failure) (33). ANGPT2 and SOFA score were significantly correlated $(\mathrm{p}<0.01)$ (Table 3$)$. In line with this, we found that COVID19 patients with acute kidney injury $(\mathrm{AKI})$ had significantly $(\mathrm{p}<0.05)$ higher ANGPT2 levels (Figure 1F) and that ANGPT2 inversely correlated $(\mathrm{p}<0.0001)$ with eGFR[creatinine] (Table 3). In contrast, we found no association of ANGPT2 and troponin I (myocardial injury) or pulmonary function $\left(\mathrm{PaO}_{2} / \mathrm{FiO}_{2}\right)$ (Table 3). The inflammatory markers CRP, TNFa, IL6, and ferritin were all significantly $(\mathrm{p}<0.0001)$ elevated in COVID-19 patients at admission (Table 2). TNFa showed a significant $(\mathrm{p}<0.01)$ correlation with ANGPT2 (Table 3). The other inflammatory markers did not correlate with ANGPT2 and neither did lactate.

\section{Hypercoagulation in critically ill COVID-19 patients}

To investigate if ANGPT2 correlated with hypercoagulation in these patients, we assessed several markers of the coagulation system summarized in Table 2. Of note, all patients received prophylactic anticoagulation therapy with Dalteparin sodium during the ICU stay (5). Platelet counts were significantly $(\mathrm{p}<0.0001)$ increased in patients at the late timepoint compared to the 
medRxiv preprint doi: https://doi.org/10.1101/2021.01.13.21249429; this version posted May 27,2021 . The copyright holder for this preprint

(which was not certified by peer review) is the author/funder, who has granted medRxiv a license to display the preprint in perpetuity. It is made available under a CC-BY-NC-ND 4.0 International license.

reference interval and the early timepoint (Table 2$)$ and showed significant $(\mathrm{p}<0.05)$ correlation with ANGPT2 (Table 3). D-dimer levels were increased $(\mathrm{p}<0.0001)$ in all patients and correlated significantly $(\mathrm{p}<0.05)$ with ANGPT2 (Table 2, 3). Fibrinogen had similar pattern and correlated $(\mathrm{p}<0.05)$ with ANGPT2 (Table 2, 3). Thromboelastography (TEG) was performed on some patients during their ICU stay. TEG maximal amplitude (MA), representing thrombus strength, was significantly increased over time in the cohort $(\mathrm{p}<0.0001)$ (Figure $1 \mathrm{H}$, Table 2$)$. The patients with an MA value $>69 \mathrm{~mm}$ had significantly $(\mathrm{p}<0.05)$ higher ANGPT2 levels (Figure $1 \mathrm{G}$ ) and there was a significant $(\mathrm{p}<0.05)$ correlation between MA and ANGPT2 (Table $3)$. In contrast, reaction time $(R)$ increased over time in the cohort $(p<0.01)$ (Table 2). We did not find differences in other TEG parameters (Table 2). Although we were unable to assess more direct measures of thrombomodulin effects (like activated protein $\mathrm{C}$ ), immunoprecipitation of circulating thrombomodulin from patient and control plasma showed binding of ANGPT2 (Figure 1I, J).

In addition to ANGPT2, other factors are likely to play additional roles for hypercoagulation in COVID-19. Von Willebrand factor (VWF) is stored and released from platelets and endothelial Wiebel Palade bodies (34). Because VWF and ANGPT2 have been reported to be stored in the same endothelial vesicles (35), we assessed plasma levels of VWF. VWF was significantly $(p<0.0001)$ elevated in all COVID-19 patients compared to healthy controls and correlated $(\mathrm{p}<0.05)$ to ANGPT2 (Figure $1 \mathrm{~K}$, Table 2, 3). ADAMTS13 is a metalloprotease produced by the liver that degrades large VWF multimers, thereby decreasing VWF's procoagulation properties $(36)$. We found that ADAMTS13 was significantly $(\mathrm{p}<0.0001)$ decreased at the late timepoint in patients later dying from COVID-19 compared to all other patients, suggesting an increased consumption of ADAMTS13 (Figure 1L). VWF correlated with ANGPT2, SOFA score, eGFR[creatinine], P-creatinine, platelet count, and TEG MA, but not with SAPS-3 and could not predict mortality at any time-point (Suppl. Table 1). Taken together, our data strongly suggest a link between ANGPT2 and the coagulation system.

\section{ANGPT2 administration decreases tail bleeding time in mice}

To expand on the in vitro studies performed by Daly et al (29) showing that ANGPT2 binds thrombomodulin, we performed in vivo studies in mice to evaluate the effect of ANGPT2 on bleeding time. We employed the tail bleeding model, which has been used extensively to evaluate the coagulation system in mice (37). Recombinant His-tagged human ANGPT2, ANGPT1, or IgG as controls, were injected 15 minutes before tail bleeding. In these experiments, $250 \mu \mathrm{g} / \mathrm{kg}$ of ANGPT2 resulted in significantly $(\mathrm{p}<0.01)$ reduced bleeding time, whereas ANGPT1 did not differ from the IgG control (Figure 2A). The resulting plasma concentrations after ANGPT2 injection correlated roughly with the injected dose (Figure 2B). To examine if ANGPT2 bound directly to thrombomodulin, we performed experiments on lung tissue after injection of $250 \mathrm{ug} / \mathrm{kg}$ ANGPT2, ANGPT1 or IgG. Thrombomodulin was immunoprecipitated, and the signals for His-tag and total thrombomodulin were evaluated. ANGPT2 showed significantly $(\mathrm{p}<0.01)$ more binding to thrombomodulin compared to IgG or ANGPT1 (Figure 2C, D).

In contrast, mice with an induced endothelial-specific knockout of Angpt 2 showed significantly ( $p<0.0001$ ) increased bleeding time (Figure 2G). ANGPT2's effect on tail bleeding time was Tie2 independent, as endothelial-specific Tie2 knockouts showed no differences in bleeding 
medRxiv preprint doi: https://doi.org/10.1101/2021.01.13.21249429; this version posted May 27, 2021. The copyright holder for this preprint (which was not certified by peer review) is the author/funder, who has granted medRxiv a license to display the preprint in perpetuity.

time (Figure 2H). Previous studies showed lack of a difference in tail bleeding time in Angpt1 knockout mice (29).

\section{ANGPT2 inhibits thrombomodulin mediated anticoagulation and activation of protein $C$}

To further study the effects of ANGPT2 on coagulation, we utilized thromboelastography (TEG) on human plasma supplemented with thrombomodulin and ANGPT2. A TEG curve from one of the high responder donors can be seen in Figure 3A with measured parameters indicated. As expected through its negative regulation on the coagulation system, thrombomodulin significantly $(\mathrm{p}<0.001)$ increased the time for coagulation to start (reaction time - TEG R) (Figure 3B, Table 4). This effect was significantly inhibited by ANGPT2 $(\mathrm{p}<0.01)$. Trends towards a thrombomodulin-induced decrease in thrombus strength (maximal amplitude - TEG MA) and its inhibition by ANGPT2 were also observed, although these effects were not statistically significant (Figure 3C). It should be noted that plasma from all donors responded to thrombomodulin and ANGPT2 but to a variable degree. ANGPT2 on its own did not affect TEG parameters (Figure 3B, C, Table 4).

Next, we investigated ANGPT2's effect on activation of protein $\mathrm{C}$ in human plasma in vitro. Human plasma was incubated with thrombomodulin with ANGPT2, ANGPT1, and control IgG to study thrombin/thrombomodulin mediated activation of protein $\mathrm{C}$. Activated protein $\mathrm{C}$ was measured with chromogenic APC substrate. As expected, the addition of thrombomodulin significantly $(\mathrm{p}<0.0001)$ increased activation of protein $\mathrm{C}$ compared to IgG, ANGPT2, and ANGPT1 alone (Figure 3D). Both ANGPT2 and ANGPT1 significantly $(p<0.0001)$ reduced thrombomodulin-mediated activation of protein C (Figure 3D).

\section{Discussion}

Our comprehensive translational approach, comprising analysis of plasma and clinical features in critically ill COVID-19 patients together with mechanistic studies in mice and in vitro, suggests a novel role for ANGPT2 in COVID-19-associated hypercoagulation. We found that elevated ANGPT2 correlated with markers of the coagulation system in plasma in COVID-19 patients, with the highest levels in patients that subsequently died from the disease. Using mice, we further found a procoagulant effect of administered ANGPT2 and an anti-coagulant effect of genetic inactivation of the Angpt2 gene. In vitro experiments with human plasma showed that ANGPT2 inhibited thrombomodulin-mediated anticoagulation and protein $\mathrm{C}$ activation. Taken together, our data suggest that elevated ANGPT2 might have an important pathogenic role in critically ill COVID-19 patients, and potentially also in other diseases with hypercoagulation. Our suggested function of ANGPT2 in hypercoagulation is summarized in Figure 4.

Circulating ANGPT2 levels correlated with severity of disease, hypercoagulation, and mortality in the studied cohort. Our results for ANGPT2 are in line with recently published data in COVID-19 patients $(13-15,38)$. The strength of our study is that we analyzed two different timepoints in these patients, at admission to the ICU and 10-14 days after admission. This revealed that ANGPT2 is increased over time in all patients in the ICU, and that non-survivors have an even further increase. We find that ANGPT2 levels at admission can significantly 
medRxiv preprint doi: https://doi.org/10.1101/2021.01.13.21249429; this version posted May 27,2021 . The copyright holder for this preprint (which was not certified by peer review) is the author/funder, who has granted medRxiv a license to display the preprint in perpetuity. It is made available under a CC-BY-NC-ND 4.0 International license .

predict mortality and correlates to the ICU indices SAPS-3 (probability of death). In addition, we find that ANGPT2 correlates significantly to indices of organ failure (SOFA score) including kidney injury (AKI, eGFR[creatinine]), but not myocardial injury (troponin I), nor pulmonary function $\left(\mathrm{PaO}_{2} / \mathrm{FiO}_{2}\right)$.

To investigate if ANGPT2 levels correlated with hypercoagulation in these patients, we assessed several markers of the coagulation system. Ideally, we would have wanted to analyze a more specific target for our hypothesis i.e. activated protein $\mathrm{C}$, but this was unsuccessful. Instead, we studied clinical available markers of the coagulation system activation including Ddimer, fibrinogen, platelet count, and TEG. All these markers indicate a hypercoagulative state in these patients that worsens over time. More importantly, we find that ANGPT2 levels correlate with all of them i.e. D-dimer, fibrinogen, platelet count, and maximal amplitude (MA) from TEG. The risk of developing venous thromboembolism in orthopedic trauma patients in known to increase when $\mathrm{MA} \geq 65 \mathrm{~mm}$, and further doubles when MA $\geq 72 \mathrm{~mm}$ (39). In this study, patients with MA >69 mm (upper reference interval) had significantly higher ANGPT2. Increased MA has previously been reported in critically ill COVID-19 patients $(5,40,41)$. Recently, thrombin-antithrombin complexes and factor VIIIa were shown to be significant upregulated in critically ill ICU-contained COVID-19 patients compared to hospitalized nonICU COVID-19 patients (42). D-dimer is widely reported to be increased in COVID-19 patients.

VWF was significantly increased in all ICU patients compared to healthy controls, but in contrast to ANGPT2, we found no differences in VWF levels between the ICU patient groups. This contrasts to a recent study reporting a correlation between VWF and mortality in ICU COVID-19 patients (42). Nevertheless, because of the suggested co-storage of ANGPT2 and VWF in endothelial Weibel Palade bodies (35), we wanted to pursue the VWF track, and therefore investigated ADAMTS13, a liver-derived plasma metalloprotease that degrades large VWF multimers and thereby decreases VWF's pro-hemostatic properties (36). Previously, decreased concentrations of ADAMTS13 have been shown to correlate with mortality in COVID-19 and septic shock patients $(15,43)$. Interestingly, ADAMTS13 levels decreased over time in the ICU in non-recovering patients in our cohort. It is plausible that this progressive decrease reflects increased consumption rather than lowered production of ADAMTS13.

Endothelial dysfunction can be mediated by ANGPT2 through its binding to Tie2 (44) and integrin $\beta 1 \alpha 5$ (26) (Figure 4). More recently, Daly et al reported that ANGPT2 can bind thrombomodulin and inhibit thrombomodulin-mediated anticoagulation in vitro (29).

Thrombin coupled to thrombomodulin converts protein $\mathrm{C}$ to activated protein C (APC), an endogenous protein that promotes fibrinolysis and inhibits thrombosis and inflammation (30) (Figure 4). ANGPT2 (and ANGPT1) binding to thrombomodulin inhibits its binding to thrombin and subsequent activation of protein C (29). APC formation may also be impaired because of down-regulation or shedding of thrombomodulin induced by inflammatory cytokines (45), and increased circulating levels of thrombomodulin have been reported in COVID-19 patients which correlated with mortality $(15,42)$. We utilized circulating thrombomodulin in immunoprecipitation experiments from COVID-19 patient and control 
medRxiv preprint doi: https://doi.org/10.1101/2021.01.13.21249429; this version posted May 27,2021 . The copyright holder for this preprint

(which was not certified by peer review) is the author/funder, who has granted medRxiv a license to display the preprint in perpetuity. It is made available under a CC-BY-NC-ND 4.0 International license.

plasma. We found that circulating thrombomodulin carried bound ANGPT2, showing that this interaction is indeed happening in vivo in both controls and patients (Figure 1). We did not find any significant difference in the ratio between ANGPT2/thrombomodulin pulled down together with thrombomodulin. We speculate that under normal conditions there is a low steady state of thrombomodulin bound ANGPT2, which increases in COVID-19 with high ANGPT2 levels and increased shedding of thrombomodulin. More studies are needed to investigate this further. While reduced levels of APC are found in a majority of patients in sepsis and are associated with increased risk of death (46-49), a recent study did not find changes of APC in critically ill COVID-19 patients (42).

To further investigate if ANGPT2 can directly affect the coagulation system in vivo, we performed several experiments in mice. One simple but highly relevant experiment to evaluate coagulation is tail bleeding time (37). In these experiments, recombinant ANGPT2 and ANGPT1 were injected before the measurement of tail bleeding time. These experiments showed that ANGPT2, but not ANGPT1, could decrease bleeding time in vivo. Immunoprecipitation of thrombomodulin from lung tissue showed binding of ANGPT2 (Figure 2). In contrast, mice with endothelial-specific deletion of Angpt2 displayed longer bleeding times. Furthermore, endothelial-specific deletion of Tie2 did not change bleeding time, excluding a Tie2-dependent mechanism in our model. Bleeding time in Angpt1 knockout mice was reported to be normal in a previous study (29). In contrast, Higgins et al, reported that heterozygous Tie 2 knockout mice had an increased thrombotic response at the site of laser injury (12). As Tie2 signaling regulates the transcription of Angpt2 (50), it is tempting to speculate that heterozygous Tie 2 knockout mice had more Angpt2 protein stored in endothelial secretory vesicles, and that increased local release of Angpt 2 occurred upon laser injury. Regardless, it is evident that more studies are needed concerning this pathway and its implications for disease.

TEG was also used to study ANGPT2 inhibition of thrombomodulin-mediated anticoagulation in freshly collected plasma from healthy donors. All donor plasma had a thrombomodulinmediated increase in reaction time that could be inhibited by ANGPT2 (Figure 3). The ability of ANGPT2 and ANGPT1 to inhibit thrombomodulin-mediated APC production was investigated in an APC assay with human plasma and a chromogenic APC substrate. In this assay, we found that both ANGPT2 and ANGPT1 could significantly reduce activation of protein $\mathrm{C}$ by approximately $50 \%$ (Figure 3), which agrees with data reported by Daly et al (29). Why is this effect elicited by ANGPT1 in vitro, but not in vivo? A possible answer is provided by Daly et al, who suggest that in the presence of both thrombomodulin and TIE2, ANGPT1 preferably binds TIE2, whereas ANGPT2 binds both thrombomodulin and TIE2 (29). Currently, we have no means of assessing the local concentrations of ANGPT2 and ANGPT1 in vivo. Endothelial expression of ANGPT2 varies extensively among vessel types and location and is upregulated in response to angiogenic and inflammatory activation. It is therefore possible that inhibition of thrombomodulin occurs only locally at sites of high ANGPT2 release. ANGPT1 on the other hand, is important for endothelial stabilization and anti-inflammatory properties through TIE2 signaling. In line with this, release of ANGPT1 in conjunction with platelet degranulation and resulting signaling through TIE2 have been shown to be important 
medRxiv preprint doi: https://doi.org/10.1101/2021.01.13.21249429; this version posted May 27,2021 . The copyright holder for this preprint (which was not certified by peer review) is the author/funder, who has granted medRxiv a license to display the preprint in perpetuity. It is made available under a CC-BY-NC-ND 4.0 International license.

for endothelial barrier closure after neutrophil extravasation (51). Although ANGPT1 might inhibit thrombomodulin in vitro, this may not be a major concern in vivo, as most studies show unchanged or decreased ANGPT1 in disease, including the current study and a large sepsis study (12).

Our data suggest that inhibition of ANGPT2 may be explored as a therapeutic approach in COVID-19 and other diseases with hypercoagulation. A compound known as Trebananib (formerly AMG386) binds to both ANGPT2 and ANGPT1 and inhibits interaction with TIE2 (52). Trebananib has been tested in multiple clinical cancer trials and has been administered to a large number of patients (53-55), and to our knowledge, coagulation disorders have not been reported as adverse effects in these trials. While Trebananib might be an interesting compound to test in COVID-19 patients, its binding and inhibition of ANGPT1-TIE2 signaling may complicate matters, as ANGPT1-TIE2 signaling in known to protect the vasculature and decrease inflammation (28). Inhibiting ANGPT1 may therefore have adverse effects. There are currently many clinical trials registered with Angiopoietin-2 antibodies, several for the treatment of solid tumors. Critically ill COVID-19 patients may benefit from these antibodies. Another very interesting compound at the preclinical stage is ABTAA, a humanized Angiopoietin-2 $\underline{B}$ inding and Tie2-Activating Antibody (28). ABTAA binds and clusters ANGPT2, converting it into a TIE2-activating molecule while simultaneously decreasing free ANGPT2, which antagonizes TIE2 signaling. ABTAA treatment has shown promising results in experimental models of sepsis (28), however, coagulation was not evaluated. Another approach would be to interfere with exocytosis and translation of ANGPT2. Several compounds can stimulate exocytosis of ANGPT2 in vitro, including thrombin, histamine and TNF $\alpha$ (21, 56). We found a significant correlation between ANGPT2 and TNF $\alpha$, and patients may benefit from anti-TNF $\alpha$ treatments (57). Studies have shown that serum concentrations of cytokines and acute phase proteins are downregulated after administration of anti-TNF $\alpha$ therapy in patients with rheumatoid arthritis, including IL-6, IL-1 receptor antagonist, serum amyloid A, haptoglobin, and fibrinogen (58-60). Markers of the coagulation system are also rapidly downregulated, with significant reductions in D-dimer and pro-thrombin fragments seen shortly after anti-TNF $\alpha$ therapy $(61)$.

We acknowledge certain limitations in our study. First, this study was neither designed nor powered to test the performance of parameters for outcome prediction. However, our findings are plausible, hypothesis-generating, and clearly deserve validation in a larger cohort of patients. Second, most of the COVID-19 patients were male, an overrepresented sex among COVID-19 patients in intensive care at the time of our study, and inference of our results to female COVID-19 patients should therefore be made with caution. Importantly, experiments in mice and analyses on donor blood had representation of both sexes.

In conclusion, we show that ANGPT2 levels in critically ill COVID-19 patients correlate with severity of disease, hypercoagulation, and mortality. In addition, we provide novel in vivo evidence for a direct role for ANGPT2 in coagulation through binding to and inhibition of thrombomodulin-mediated anticoagulation. These findings suggest that inhibition of ANGPT2 
medRxiv preprint doi: https://doi.org/10.1101/2021.01.13.21249429; this version posted May 27, 2021. The copyright holder for this preprint (which was not certified by peer review) is the author/funder, who has granted medRxiv a license to display the preprint in perpetuity.

might not only benefit critically ill COVID-19 patients but also other patients with hypercoagulation.

\section{Methods}

Study design and patients

The present study is part of a prospective single-center observational study at the ICU at Uppsala University Hospital. During the first wave between March 13 and August 14, 2020, 123 patients older than 18 years of age were included in the study. All patients were diagnosed with COVID-19 by positive reverse-transcription PCR from nasopharyngeal swabs. Samples from 61 patients were included in the study based on severity of disease and length of stay. 40 patients with extended length of stay $>10$ days were included with one sample at admission, and one sample after at least 10 days. In addition, 20 patients with severe disease but shorter length of stay were included with one sample at admission only. Apart from the customary ICU care and medications, all patients received thromboprophylaxis with dalteparin sodium at 100 $\mathrm{IU} / \mathrm{kg}$. Blood was sampled in 0.129 M trisodium citrate tubes (9NC BD Vacutainer, Becton Dickinson) and stored as plasma at $-80^{\circ} \mathrm{C}$ until analysis.

Clinical data were recorded prospectively, including medical history, medications, physiological data, and date of death. The Simplified Acute Physiology Score 3 (SAPS-3) and Sequential Organ Failure Assessment (SOFA) score, circulatory support, and respiratory support data were collected as detailed in the Results section (Table 1, 2).

Healthy control plasma was collected after consent from forty consecutive adult blood donors (43\% females, 43 (37-49) years old) visiting the Blood Central at Uppsala University Hospital on June 23, 2020. TEG was performed on freshly collected plasma from 7 donors (4 females/3 males, 30-50 years old). In addition, freshly collected plasma from 5 ICU hospitalized COVID19 patients were used for immunoprecipitation of thrombomodulin and ANGPT2 blotting.

\section{Blood examinations}

All routine lab tests were performed at the hospital's clinical chemistry department. First blood sample was collected 1-4 days after admission, the second 10-14 days after admission. ELISA's were used to measure plasma protein concentrations for Angiopoietin-2 (DANG20, R\&D Systems), Angiopoietin-1 (DANG10, R\&D Systems), von Willebrand factor (ab108918, Abcam), and ADAMTS13 (ab234559, Abcam) according to the manufacturer's instructions. To investigate if binding of ANGPT2 to thrombomodulin occurred in patients, we utilized immunoprecipitation of circulating thrombomodulin in plasma and blotted for ANGPT2 (details below).

\section{Mice}

Floxed Angpt 2 mice (62) and Tie2 mice (62) were crossed to tamoxifen inducible Cdh5-Cre ${ }^{\text {ERT2 }}$ (63) mice to generate endothelial specific knockout of Angpt2 (Angpt2 ${ }^{\mathrm{iECKO}}$ ) and Tie2 $\left(\mathrm{Tie} 2^{i E C K O}\right.$ ). Controls were littermate mice with wt/wt alleles for Angpt2 (WT) and Tie2 (WT). Mice were genotyped with primers for Angpt2 (for 5'-GGGAAACCTCAACACTCCAA and rev 5'- ACACCGGCCTCAAGACACAC, wt 222 bp, floxed 258 bp), Tie2 flox (for 5'TCCTTGCCGCCAACTTGTAAAC and rev 5'- TTTCCTCCTCTCCTGACTACTCC, 604 
medRxiv preprint doi: https://doi.org/10.1101/2021.01.13.21249429; this version posted May 27, 2021. The copyright holder for this preprint (which was not certified by peer review) is the author/funder, who has granted medRxiv a license to display the preprint in perpetuity. It is made available under a CC-BY-NC-ND 4.0 International license .

bp), Tie2 wt (for 5'- TCCTTGCCGCCAACTTGTAAAC and rev 5'AGCAAGCTGACTCCACAGAGAAC, 175 bp), and general Cre allele (for 5ATGTCCAATTTACTGACCG and rev 5'-CGCCGCA TAACCAGTGAA, 673 bp). Knockout was induced with 3 doses of tamoxifen $(2 \mathrm{mg}$ ) in peanut oil by oral gavage at 4 weeks of age. Mice for other experiment came from in house breeding on a C57BL6/J background. All experiments were performed in both female and male mice.

\section{Tail bleeding assay}

Mice with isoflurane anesthesia were subjected to surgical dissection of the tail $(3 \mathrm{~mm}$ from the tip). The tail was prewarmed for 2 minutes before dissection and immediately after immersed in buffered saline prewarmed to $37^{\circ} \mathrm{C}$. The time of bleeding was recorded. The tail bleeding assay were performed in 6-12-week-old Angpt $2^{\mathrm{iECKO}}$ Tie $^{\mathrm{iECKO}}$, and control mice (WT).

In addition, the same experiment was performed in WT mice 15 minutes after receiving an i.p. injection of a recombinant human His tagged fragments of ANGPT2 (ab220589, Abcam), ANGPT1 (ab69492, Abcam), Albumin (ab217817, Abcam), or IgG (ab219660, Abcam). The proteins were diluted in PBS and injected at $25 \mu \mathrm{g} / \mathrm{kg}$ and $250 \mu \mathrm{g} / \mathrm{kg}$ body weight. After the assay, heart puncture was performed to collect blood diluted 1:10 in citate-dextrose anticoagulant (C3821, Sigma), centrifuged and prepared as above. Lungs were harvested, snap frozen and stored at $-80^{\circ} \mathrm{C}$ for later protein analysis.

\section{ANGPT2 association with thrombomodulin in vivo}

Plasma concentrations of injected recombinant human ANGPT2 was measured by ELISA as above (DANG20, R\&D Systems). Immunoprecipitation experiments were performed to evaluate the binding of ANGPT2 and ANGPT1 to thrombomodulin after injection. Lung tissue was homogenized in RIPA buffer (89901, Pierce) with proteas and phosphatase inhibitor (A32959, Pierce). Lung lysates were immunoprecipitated with a rabbit anti-mouse thrombomodulin antibody (ab230010, Abcam) attached to protein G conjugated Dynabeads (10004D, Thermo Fisher Scientific). Immunoprecipitated proteins were separated on 4-20\% Mini Protean TGX gels (4561094, Biorad) and then transferred using Trans-blot turbo $0.2 \mu \mathrm{m}$ PVDF membranes (1704156, Biorad). Blots were blocked with 5\% BSA for $1 \mathrm{~h}$ and incubated overnight with mouse anti-6X His tag antibody (27E8, 2366, Cell Signaling). After washing and incubating with anti-mouse IgG-HRP conjugated secondary antibody (NA931, Sigma), proteins were visualized using ECL plus detection reagents (GERPN2232, Sigma). Blots were stripped with Re-Blot Plus Strong solution (2504, Millipore), blocked, and probed with antithrombomodulin antibody followed by anti-rabbit HRP conjugated secondary antibody (711035-152, Jackson Immuno Research). Band density was quantified with ImageJ (NIH). Immunoprecipitation of thrombomodulin from control and patient plasma was performed as above with a rabbit anti-human thrombomodulin antibody (ab108189, Abcam) attached to protein $\mathrm{G}$ conjugated Dynabeads in $200 \mu \mathrm{l}$ of plasma. ANGPT2 signal was detected with rabbit anti-human ANGPT2 (ab155106, Abcam) and donkey anti-rabbit IgG-HRP conjugated secondary antibody (711-035-152, Jackson Immuno Research). After stripping, the blot was probed with anti-human thrombomodulin antibody followed by anti-rabbit HRP conjugated secondary antibody as above. An ANGPT2 fragment (26 kDa, Ab220589, Abcam) was used to assure specificity of the ANGPT2 antibody in the experiments. All blots showed band sizes 
medRxiv preprint doi: https://doi.org/10.1101/2021.01.13.21249429; this version posted May 27, 2021. The copyright holder for this preprint (which was not certified by peer review) is the author/funder, who has granted medRxiv a license to display the preprint in perpetuity.

predicted by the manufacturers. Dynabeads without conjugated thrombomodulin antibody was used as negative control.

\section{Effect of ANGPT on thrombomodulin dependent anticoagulation}

TEG on kaolin activated plasma was utilized to evaluate the effect of ANGPT2 on thrombomodulin dependent anticoagulation. Freshly drawn human citrate plasma, from both female and male donors, was incubated in kaolin tubes with $1000 \mathrm{ng} / \mathrm{ml} \mathrm{recombinant}$ thrombomodulin (3947-PA-010, R\&D Systems) and $1000 \mathrm{ng} / \mathrm{ml}$ ANGPT2 (ab220589, Abcam) at room temperature for 20 minutes. Analysis was carried out on a TEG5000 (Nordic Biolabs) for 15 minutes + reaction time $(\mathrm{R})$. The measurements were started by the addition of plasma to TEG cups containing $20 \mu 10.2 \mathrm{M} \mathrm{CaCl}_{2}$. Samples were run in duplicate and averaged. A sample without additives was run at the start and end of the experiment and averaged as control.

\section{Effect of ANGPT2 on thrombomodulin dependent activation of protein C}

Pooled plasma from healthy controls was incubated with the same volume of $6 \mathrm{mM} \mathrm{CaCl}_{2}$ with $0.2 \mathrm{U} / \mathrm{ml}$ thrombin (T8885, Sigma), $1000 \mathrm{ng} / \mathrm{ml}$ of recombinant thrombomodulin (3947-PA010, R\&D Systems), ANGPT2 (ab220589, Abcam), ANGPT1 (ab69492, Abcam), IgG (ab219660, Abcam) at $37^{\circ} \mathrm{C}$ for 30 minutes. The reaction was terminated by addition of 0.2 $\mathrm{U} / \mathrm{ml}$ hirudin $\left(\mathrm{H} 0393\right.$, Sigma) at $37^{\circ} \mathrm{C}$ for 10 minutes. The generation of APC was evaluated by adding chromogenic APC substrate. After addition of $50 \mu \mathrm{l}$ chromogenic APC substrate (229021, Biophen CS-21(66)) the increase in absorbance was measured at $405 \mathrm{~nm}$ for 8 minutes (linear phase) at $37^{\circ} \mathrm{C}$ in a temperature-controlled plate reader (Synergy HT, Biotek). The area under the curve was used to calculate APC concentrations expressed as arbitrary units (a.u.).

\section{Study approval}

The study was approved by the Swedish National Ethical Review Agency (EPM; No. 202001623). Informed consent was obtained from the patient, or next of kin if the patient was unable to give consent. Healthy blood donor samples were approved under ethical permit No 01/367. The Declaration of Helsinki and its subsequent revisions were followed. The protocol for the study was registered (ClinicalTrials ID: NCT04316884); STROBE guidelines were followed for reporting.

All animal experiments were approved by the Uppsala Committee of Ethics of Animal Experiments (approved permit number 5.8.18-04862-2020 and 5.8.18-03858-2021) and were conducted according to guidelines established by the Swedish Board of Agriculture.

\section{Statistics}

Data are expressed as geometric mean \pm geometric $95 \%$ CI. To test for statistical differences, we utilized Student's $t$-test or ANOVA ( $>2$ groups) where appropriate. ANOVA was followed by Bonferroni's post hoc test. Data was unevenly normal distributed, and data was log transformed before statistical analysis. Pearson's correlation was used to measure dependence between two variables except for SAPS-3, SOFA score, and TEG MA where non-parametric Spearman's correlation was used. Fisher's exact test was used to evaluate patients' results in comparison to a given reference interval representing the normal range based on mean $\pm 2 \mathrm{SD}$ (as calculated in the clinic). Kaplan-Meier plots with Log-rank test were used to estimate the 
medRxiv preprint doi: https://doi.org/10.1101/2021.01.13.21249429; this version posted May 27, 2021. The copyright holder for this preprint (which was not certified by peer review) is the author/funder, who has granted medRxiv a license to display the preprint in perpetuity.

probability of survival. The optimal cut-off value was determined from Receiver Operating Characteristics (ROC) curve analysis, and the cut-off with the highest likelihood ratio was selected i.e. for ANGPT2, area under the ROC curve $\mathrm{p}=0.0004$; cut-off $8.3 \mathrm{ng} / \mathrm{ml}$ with likelihood ratio 23.5; VWF, no significant area under the ROC curve.

All statistical analysis was done in GraphPad Prism 8. All analyses were 2-sided and a $\mathrm{p}<0.05$ was considered significant. $*<0.05, * *<0.01, * * *<0.001$, and $* * * *<0.0001$.

\section{Author contributions}

Designing research studies: $\mathrm{MH}, \mathrm{MJ}$

Conducting experiments: $\mathrm{MH}, \mathrm{KF}, \mathrm{AL}, \mathrm{MJ}$

Acquiring data: $\mathrm{MH}, \mathrm{KF}, \mathrm{AL}, \mathrm{RF}, \mathrm{ML}, \mathrm{MJ}$

Analyzing data: KF, MJ

Providing reagents: $\mathrm{SEQ}, \mathrm{CB}, \mathrm{MJ}$

Writing the manuscript: MH, KF, AL, SEQ, CB, RF, ML, MJ

\section{Acknowledgement}

We thank Jana Chmielniakova, Pia Peterson, and Cecilia Olsson at Uppsala University for technical assistance, as well as research nurses Joanna Wessbergh and Elin Söderman, and the biobank assistants Labolina Spång, Erik Danielsson and Philip Karlsson for their expertise in compiling patient samples. We thank Peetra Magnusson at Uppsala University for valuable comments on the manuscript.

\section{Funding}

The study was funded by the SciLifeLab/KAW national COVID-19 research program project grant to MH (KAW 2020.0182 and KAW2020.0241), the Swedish Heart-Lung Foundation to MH (20210089) the Swedish Research Council grant to RF (2014-02569 and 2014-07606), and Swedish Research Council grant (2012-865), Åke Wiberg Foundation, Magnus Bergwall Foundation, IGP Young Investigator Award to MJ. The laboratory of C.B. is funded by grants from the Swedish Research Council, the Swedish Cancer Society, and the Knut and Alice Wallenberg Foundation.

Data and materials availability: All data are presented within the paper, individual level data can be made available on reasonable request (https://doi.org/10.17044/scilifelab.14229410).

\section{References}

1. F. Zhou, T. Yu, R. Du, G. Fan, Y. Liu, Z. Liu, J. Xiang, Y. Wang, B. Song, X. Gu, L. Guan, Y. Wei, H. Li, X. Wu, J. Xu, S. Tu, Y. Zhang, H. Chen, B. Cao, Clinical course and risk factors for mortality of adult inpatients with COVID-19 in Wuhan, China: a retrospective cohort study. Lancet 395, 1054-1062 (2020).

2. H. Al-Samkari, R. S. Karp Leaf, W. H. Dzik, J. C. T. Carlson, A. E. Fogerty, A. Waheed, K. Goodarzi, P. K. Bendapudi, L. Bornikova, S. Gupta, D. E. Leaf, D. J. Kuter, R. P. Rosovsky, COVID-19 and coagulation: bleeding and thrombotic manifestations of SARS-CoV-2 infection. Blood 136, 489-500 (2020). 
medRxiv preprint doi: https://doi.org/10.1101/2021.01.13.21249429; this version posted May 27,2021 . The copyright holder for this preprint (which was not certified by peer review) is the author/funder, who has granted medRxiv a license to display the preprint in perpetuity.

3. F. A. Klok, M. Kruip, N. J. M. van der Meer, M. S. Arbous, D. Gommers, K. M. Kant, F. H. J. Kaptein, J. van Paassen, M. A. M. Stals, M. V. Huisman, H. Endeman, Incidence of thrombotic complications in critically ill ICU patients with COVID-19. Thromb Res 191, 145-147 (2020).

4. D. E. Leisman, C. S. Deutschman, M. Legrand, Facing COVID-19 in the ICU: vascular dysfunction, thrombosis, and dysregulated inflammation. Intensive Care Med 46, 1105 1108 (2020).

5. K. Stattin, M. Lipcsey, H. Andersson, E. Ponten, S. Bulow Anderberg, A. Gradin, A. Larsson, N. Lubenow, M. von Seth, S. Rubertsson, M. Hultstrom, R. Frithiof, Inadequate prophylactic effect of low-molecular weight heparin in critically ill COVID19 patients. J Crit Care 60, 249-252 (2020).

6. Y. Wu, X. Xu, Z. Chen, J. Duan, K. Hashimoto, L. Yang, C. Liu, C. Yang, Nervous system involvement after infection with COVID-19 and other coronaviruses. Brain, behavior, and immunity 87, 18-22 (2020).

7. N. Tang, D. Li, X. Wang, Z. Sun, Abnormal coagulation parameters are associated with poor prognosis in patients with novel coronavirus pneumonia. $J$ Thromb Haemost 18, 844-847 (2020).

8. W. J. Guan, Z. Y. Ni, Y. Hu, W. H. Liang, C. Q. Ou, J. X. He, L. Liu, H. Shan, C. L. Lei, D. S. C. Hui, B. Du, L. J. Li, G. Zeng, K. Y. Yuen, R. C. Chen, C. L. Tang, T. Wang, P. Y. Chen, J. Xiang, S. Y. Li, J. L. Wang, Z. J. Liang, Y. X. Peng, L. Wei, Y. Liu, Y. H. Hu, P. Peng, J. M. Wang, J. Y. Liu, Z. Chen, G. Li, Z. J. Zheng, S. Q. Qiu, J. Luo, C. J. Ye, S. Y. Zhu, N. S. Zhong, Clinical Characteristics of Coronavirus Disease 2019 in China. N Engl J Med 382, 1708-1720 (2020).

9. C. Huang, Y. Wang, X. Li, L. Ren, J. Zhao, Y. Hu, L. Zhang, G. Fan, J. Xu, X. Gu, Z. Cheng, T. Yu, J. Xia, Y. Wei, W. Wu, X. Xie, W. Yin, H. Li, M. Liu, Y. Xiao, H. Gao, L. Guo, J. Xie, G. Wang, R. Jiang, Z. Gao, Q. Jin, J. Wang, B. Cao, Clinical features of patients infected with 2019 novel coronavirus in Wuhan, China. Lancet 395, 497-506 (2020).

10. A. Leligdowicz, M. Richard-Greenblatt, J. Wright, V. M. Crowley, K. C. Kain, Endothelial Activation: The Ang/Tie Axis in Sepsis. Front Immunol 9, 838 (2018).

11. F. Li, R. Yin, Q. Guo, Circulating angiopoietin-2 and the risk of mortality in patients with acute respiratory distress syndrome: a systematic review and meta-analysis of 10 prospective cohort studies. Therapeutic advances in respiratory disease 14, 1753466620905274 (2020).

12. S. J. Higgins, K. De Ceunynck, J. A. Kellum, X. Chen, X. Gu, S. A. Chaudhry, S. Schulman, T. A. Libermann, S. Lu, N. I. Shapiro, D. C. Christiani, R. Flaumenhaft, S. M. Parikh, Tie2 protects the vasculature against thrombus formation in systemic inflammation. J Clin Invest 128, 1471-1484 (2018).

13. D. M. Smadja, C. L. Guerin, R. Chocron, N. Yatim, J. Boussier, N. Gendron, L. Khider, J. Hadjadj, G. Goudot, B. Debuc, P. Juvin, C. Hauw-Berlemont, J. L. Augy, N. Peron, E. Messas, B. Planquette, O. Sanchez, B. Charbit, P. Gaussem, D. Duffy, B. Terrier, T. Mirault, J. L. Diehl, Angiopoietin-2 as a marker of endothelial activation is a good predictor factor for intensive care unit admission of COVID-19 patients. Angiogenesis, (2020).

14. A. B. Pine, M. L. Meizlish, G. Goshua, C. H. Chang, H. Zhang, J. Bishai, P. Bahel, A. Patel, R. Gbyli, J. M. Kwan, C. H. Won, C. Price, C. S. Dela Cruz, S. Halene, D. van Dijk, J. Hwa, A. I. Lee, H. J. Chun, Circulating markers of angiogenesis and endotheliopathy in COVID-19. Pulm Circ 10, 2045894020966547 (2020). 
medRxiv preprint doi: https://doi.org/10.1101/2021.01.13.21249429; this version posted May 27, 2021. The copyright holder for this preprint (which was not certified by peer review) is the author/funder, who has granted medRxiv a license to display the preprint in perpetuity. It is made available under a CC-BY-NC-ND 4.0 International license.

15. A. Rovas, I. Osiaevi, K. Buscher, J. Sackarnd, P.-R. Tepasse, M. Fobker, J. Kühn, S. Braune, U. Göbel, G. Thölking, A. Gröschel, H. Pavenstädt, H. Vink, P. Kümpers, Microvascular dysfunction in COVID-19: the MYSTIC study. Angiogenesis, (2020).

16. A. Lukasz, C. Hillgruber, H. Oberleithner, K. Kusche-Vihrog, H. Pavenstadt, A. Rovas, B. Hesse, T. Goerge, P. Kumpers, Endothelial glycocalyx breakdown is mediated by angiopoietin-2. Cardiovascular research 113, 671-680 (2017).

17. C. C. Ghosh, S. David, R. Zhang, A. Berghelli, K. Milam, S. J. Higgins, J. Hunter, A. Mukherjee, Y. Wei, M. Tran, F. Suber, L. Kobzik, K. C. Kain, S. Lu, A. Santel, K. Yano, P. Guha, D. J. Dumont, D. C. Christiani, S. M. Parikh, Gene control of tyrosine kinase TIE2 and vascular manifestations of infections. Proc Natl Acad Sci U S A 113, 2472-2477 (2016).

18. A. L. Wong, Z. A. Haroon, S. Werner, M. W. Dewhirst, C. S. Greenberg, K. G. Peters, Tie2 expression and phosphorylation in angiogenic and quiescent adult tissues. Circ Res 81, 567-574 (1997).

19. G. Thurston, J. S. Rudge, E. Ioffe, H. Zhou, L. Ross, S. D. Croll, N. Glazer, J. Holash, D. M. McDonald, G. D. Yancopoulos, Angiopoietin-1 protects the adult vasculature against plasma leakage. Nature Medicine 6, 460-463 (2000).

20. G. Thurston, C. Suri, K. Smith, J. McClain, T. N. Sato, G. D. Yancopoulos, D. M. McDonald, Leakage-resistant blood vessels in mice transgenically overexpressing angiopoietin-1. Science 286, 2511-2514 (1999).

21. A. V. Benest, K. Kruse, S. Savant, M. Thomas, A. M. Laib, E. K. Loos, U. Fiedler, H. G. Augustin, Angiopoietin-2 is critical for cytokine-induced vascular leakage. PloS one 8, e70459 (2013).

22. U. Fiedler, Y. Reiss, M. Scharpfenecker, V. Grunow, S. Koidl, G. Thurston, N. W. Gale, M. Witzenrath, S. Rosseau, N. Suttorp, A. Sobke, M. Herrmann, K. T. Preissner, P. Vajkoczy, H. G. Augustin, Angiopoietin-2 sensitizes endothelial cells to TNF-[alpha] and has a crucial role in the induction of inflammation. Nat Med 12, 235-239 (2006).

23. T. Ziegler, J. Horstkotte, C. Schwab, V. Pfetsch, K. Weinmann, S. Dietzel, I. Rohwedder, R. Hinkel, L. Gross, S. Lee, J. Hu, O. Soehnlein, W. M. Franz, M. Sperandio, U. Pohl, M. Thomas, C. Weber, H. G. Augustin, R. Fassler, U. Deutsch, C. Kupatt, Angiopoietin 2 mediates microvascular and hemodynamic alterations in sepsis. J Clin Invest, (2013).

24. S. David, A. Mukherjee, C. C. Ghosh, M. Yano, E. V. Khankin, J. B. Wenger, S. A. Karumanchi, N. I. Shapiro, S. M. Parikh, Angiopoietin-2 may contribute to multiple organ dysfunction and death in sepsis*. Crit Care Med 40, 3034-3041 (2012).

25. H. T. Yuan, E. V. Khankin, S. A. Karumanchi, S. M. Parikh, Angiopoietin 2 is a partial agonist/antagonist of Tie2 signaling in the endothelium. Molecular and cellular biology 29, 2011-2022 (2009).

26. L. Hakanpaa, T. Sipila, V. M. Leppanen, P. Gautam, H. Nurmi, G. Jacquemet, L. Eklund, J. Ivaska, K. Alitalo, P. Saharinen, Endothelial destabilization by angiopoietin2 via integrin betal activation. Nature communications 6, 5962 (2015).

27. C. C. Drost, A. Rovas, K. Kusche-Vihrog, P. Van Slyke, H. Kim, V. C. Hoang, J. T. Maynes, D. O. Wennmann, H. Pavenstadt, W. Linke, A. Lukasz, B. Hesse, P. Kumpers, Tie2 Activation Promotes Protection and Reconstitution of the Endothelial Glycocalyx in Human Sepsis. Thromb Haemost 119, 1827-1838 (2019).

28. S. Han, S. J. Lee, K. E. Kim, H. S. Lee, N. Oh, I. Park, E. Ko, S. J. Oh, Y. S. Lee, D. Kim, S. Lee, D. H. Lee, K. H. Lee, S. Y. Chae, J. H. Lee, S. J. Kim, H. C. Kim, S. Kim, S. H. Kim, C. Kim, Y. Nakaoka, Y. He, H. G. Augustin, J. Hu, P. H. Song, Y. I. Kim, P. Kim, I. Kim, G. Y. Koh, Amelioration of sepsis by TIE2 activation-induced vascular protection. Sci Transl Med 8, 335ra355 (2016). 
medRxiv preprint doi: https://doi.org/10.1101/2021.01.13.21249429; this version posted May 27, 2021. The copyright holder for this preprint

29. C. Daly, X. Qian, C. Castanaro, E. Pasnikowski, X. Jiang, B. R. Thomson, S. E. Quaggin, N. Papadopoulos, Y. Wei, J. S. Rudge, G. Thurston, G. D. Yancopoulos, S. Davis, Angiopoietins bind thrombomodulin and inhibit its function as a thrombin cofactor. Scientific reports $\mathbf{8 ,} 505$ (2018).

30. C. T. Esmon, Inflammation and the activated protein $\mathrm{C}$ anticoagulant pathway. Semin Thromb Hemost 32 Suppl 1, 49-60 (2006).

31. T. Ito, J. Thachil, H. Asakura, J. H. Levy, T. Iba, Thrombomodulin in disseminated intravascular coagulation and other critical conditions-a multi-faceted anticoagulant protein with therapeutic potential. Critical care (London, England) 23, 280 (2019).

32. B. Isermann, S. B. Hendrickson, M. Zogg, M. Wing, M. Cummiskey, Y. Y. Kisanuki, M. Yanagisawa, H. Weiler, Endothelium-specific loss of murine thrombomodulin disrupts the protein $\mathrm{C}$ anticoagulant pathway and causes juvenile-onset thrombosis. $J$ Clin Invest 108, 537-546 (2001).

33. J. L. Vincent, R. Moreno, J. Takala, S. Willatts, A. De Mendonca, H. Bruining, C. K. Reinhart, P. M. Suter, L. G. Thijs, The SOFA (Sepsis-related Organ Failure Assessment) score to describe organ dysfunction/failure. On behalf of the Working Group on Sepsis-Related Problems of the European Society of Intensive Care Medicine. Intensive Care Med 22, 707-710 (1996).

34. K. M. Valentijn, J. Eikenboom, Weibel-Palade bodies: a window to von Willebrand disease. J Thromb Haemost 11, 581-592 (2013).

35. U. Fiedler, M. Scharpfenecker, S. Koidl, A. Hegen, V. Grunow, J. M. Schmidt, W. Kriz, G. Thurston, H. G. Augustin, The Tie-2 ligand angiopoietin-2 is stored in and rapidly released upon stimulation from endothelial cell Weibel-Palade bodies. Blood 103, 41504156 (2004).

36. K. Fujikawa, H. Suzuki, B. McMullen, D. Chung, Purification of human von Willebrand factor-cleaving protease and its identification as a new member of the metalloproteinase family. Blood 98, 1662-1666 (2001).

37. T. K. Greene, A. Schiviz, W. Hoellriegl, M. Poncz, E. M. Muchitsch, S. Animal Models Subcommittee of the, I. Standardization Committee Of The, Towards a standardization of the murine tail bleeding model. J Thromb Haemost 8, 2820-2822 (2010).

38. M. Meizlish, A. Pine, G. Goshua, C.-H. Chang, H. Zhang, J. Bishai, P. Bahel, A. Patel, R. Gbyli, J. Kwan, C. Price, C. Dela Cruz, S. Halene, D. van Dijk, J. Hwa, A. I. Lee, H. J. Chun, Circulating Markers of Angiogenesis and Endotheliopathy in COVID-19. 2020.2006.2029.20140376 (2020).

39. J. L. Gary, P. S. Schneider, M. Galpin, Z. Radwan, J. W. Munz, T. S. Achor, M. L. Prasarn, B. A. Cotton, Can Thrombelastography Predict Venous Thromboembolic Events in Patients With Severe Extremity Trauma? J Orthop Trauma 30, 294-298 (2016).

40. L. Spiezia, A. Boscolo, F. Poletto, L. Cerruti, I. Tiberio, E. Campello, P. Navalesi, P. Simioni, COVID-19-Related Severe Hypercoagulability in Patients Admitted to Intensive Care Unit for Acute Respiratory Failure. Thromb Haemost 120, 998-1000 (2020).

41. M. Panigada, N. Bottino, P. Tagliabue, G. Grasselli, C. Novembrino, V. Chantarangkul, A. Pesenti, F. Peyvandi, A. Tripodi, Hypercoagulability of COVID-19 patients in intensive care unit: A report of thromboelastography findings and other parameters of hemostasis. 18, 1738-1742 (2020).

42. G. Goshua, A. B. Pine, M. L. Meizlish, C. H. Chang, H. Zhang, P. Bahel, A. Baluha, N. Bar, R. D. Bona, A. J. Burns, C. S. Dela Cruz, A. Dumont, S. Halene, J. Hwa, J. Koff, H. Menninger, N. Neparidze, C. Price, J. M. Siner, C. Tormey, H. M. Rinder, H. J. 
medRxiv preprint doi: https://doi.org/10.1101/2021.01.13.21249429; this version posted May 27, 2021. The copyright holder for this preprint

Chun, A. I. Lee, Endotheliopathy in COVID-19-associated coagulopathy: evidence from a single-centre, cross-sectional study. Lancet Haematol 7, e575-e582 (2020).

43. V. Peigne, E. Azoulay, I. Coquet, E. Mariotte, M. Darmon, P. Legendre, N. Adoui, A. Marfaing-Koka, M. Wolf, B. Schlemmer, A. Veyradier, The prognostic value of ADAMTS13 (a disintegrin and metalloprotease with thrombospondin type 1 repeats, member 13) deficiency in septic shock patients involves interleukin-6 and is not dependent on disseminated intravascular coagulation. Critical care (London, England) 17, R273 (2013).

44. S. Davis, T. H. Aldrich, P. F. Jones, A. Acheson, D. L. Compton, V. Jain, T. E. Ryan, J. Bruno, C. Radziejewski, P. C. Maisonpierre, G. D. Yancopoulos, Isolation of angiopoietin-1, a ligand for the TIE2 receptor, by secretion-trap expression cloning. Cell 87, 1161-1169 (1996).

45. M. W. Boehme, Y. Deng, U. Raeth, A. Bierhaus, R. Ziegler, W. Stremmel, P. P. Nawroth, Release of thrombomodulin from endothelial cells by concerted action of TNF-alpha and neutrophils: in vivo and in vitro studies. Immunology 87, 134-140 (1996).

46. F. Fourrier, C. Chopin, J. Goudemand, S. Hendrycx, C. Caron, A. Rime, A. Marey, P. Lestavel, Septic shock, multiple organ failure, and disseminated intravascular coagulation. Compared patterns of antithrombin III, protein $\mathrm{C}$, and protein $\mathrm{S}$ deficiencies. Chest 101, 816-823 (1992).

47. J. A. Lorente, L. J. Garcia-Frade, L. Landin, R. de Pablo, C. Torrado, E. Renes, A. Garcia-Avello, Time course of hemostatic abnormalities in sepsis and its relation to outcome. Chest 103, 1536-1542 (1993).

48. J. Boldt, M. Papsdorf, A. Rothe, B. Kumle, S. Piper, Changes of the hemostatic network in critically ill patients--is there a difference between sepsis, trauma, and neurosurgery patients? Crit Care Med 28, 445-450 (2000).

49. D. Powars, R. Larsen, J. Johnson, T. Hulbert, T. Sun, M. J. Patch, R. Francis, L. Chan, Epidemic meningococcemia and purpura fulminans with induced protein $\mathrm{C}$ deficiency. Clin Infect Dis 17, 254-261 (1993).

50. D. Y. Park, J. Lee, J. Kim, K. Kim, S. Hong, S. Han, Y. Kubota, H. G. Augustin, L. Ding, J. W. Kim, H. Kim, Y. He, R. H. Adams, G. Y. Koh, Plastic roles of pericytes in the blood-retinal barrier. Nature communications 8, 15296 (2017).

51. L. J. Braun, R. I. Stegmeyer, K. Schafer, S. Volkery, S. M. Currie, B. Kempe, A. F. Nottebaum, D. Vestweber, Platelets docking to VWF prevent leaks during leukocyte extravasation by stimulating Tie-2. Blood 136, 627-639 (2020).

52. J. Oliner, H. Min, J. Leal, D. Yu, S. Rao, E. You, X. Tang, H. Kim, S. Meyer, S. J. Han, N. Hawkins, R. Rosenfeld, E. Davy, K. Graham, F. Jacobsen, S. Stevenson, J. Ho, Q. Chen, T. Hartmann, M. Michaels, M. Kelley, L. Li, K. Sitney, F. Martin, J. R. Sun, N. Zhang, J. Lu, J. Estrada, R. Kumar, A. Coxon, S. Kaufman, J. Pretorius, S. Scully, R. Cattley, M. Payton, S. Coats, L. Nguyen, B. Desilva, A. Ndifor, I. Hayward, R. Radinsky, T. Boone, R. Kendall, Suppression of angiogenesis and tumor growth by selective inhibition of angiopoietin-2. Cancer cell 6, 507-516 (2004).

53. B. Y. Karlan, A. M. Oza, G. E. Richardson, D. M. Provencher, V. L. Hansen, M. Buck, S. K. Chambers, P. Ghatage, C. H. Pippitt, Jr., J. V. Brown, 3rd, A. Covens, R. V. Nagarkar, M. Davy, C. A. Leath, 3rd, H. Nguyen, D. E. Stepan, D. M. Weinreich, M. Tassoudji, Y. N. Sun, I. B. Vergote, Randomized, double-blind, placebo-controlled phase II study of AMG 386 combined with weekly paclitaxel in patients with recurrent ovarian cancer. Journal of clinical oncology : official journal of the American Society of Clinical Oncology 30, 362-371 (2012). 
medRxiv preprint doi: https://doi.org/10.1101/2021.01.13.21249429; this version posted May 27, 2021. The copyright holder for this preprint (which was not certified by peer review) is the author/funder, who has granted medRxiv a license to display the preprint in perpetuity.

54. B. J. Monk, A. Poveda, I. Vergote, F. Raspagliesi, K. Fujiwara, D. S. Bae, A. Oaknin, I. Ray-Coquard, D. M. Provencher, B. Y. Karlan, C. Lhomme, G. Richardson, D. G. Rincon, R. L. Coleman, T. J. Herzog, C. Marth, A. Brize, M. Fabbro, A. Redondo, A. Bamias, M. Tassoudji, L. Navale, D. J. Warner, A. M. Oza, Anti-angiopoietin therapy with trebananib for recurrent ovarian cancer (TRINOVA-1): a randomised, multicentre, double-blind, placebo-controlled phase 3 trial. The Lancet. Oncology 15, 799-808 (2014).

55. R. S. Herbst, D. Hong, L. Chap, R. Kurzrock, E. Jackson, J. M. Silverman, E. Rasmussen, Y. N. Sun, D. Zhong, Y. C. Hwang, J. L. Evelhoch, J. D. Oliner, N. Le, L. S. Rosen, Safety, pharmacokinetics, and antitumor activity of AMG 386, a selective angiopoietin inhibitor, in adult patients with advanced solid tumors. Journal of clinical oncology : official journal of the American Society of Clinical Oncology 27, 3557-3565 (2009).

56. C. Jang, Y. J. Koh, N. K. Lim, H. J. Kang, D. H. Kim, S. K. Park, G. M. Lee, C. J. Jeon, G. Y. Koh, Angiopoietin-2 exocytosis is stimulated by sphingosine-1-phosphate in human blood and lymphatic endothelial cells. Arteriosclerosis, thrombosis, and vascular biology 29, 401-407 (2009).

57. P. C. Robinson, D. Richards, H. L. Tanner, M. Feldmann, Accumulating evidence suggests anti-TNF therapy needs to be given trial priority in COVID-19 treatment. Lancet Rheumatol 2, e653-e655 (2020).

58. P. Charles, M. J. Elliott, D. Davis, A. Potter, J. R. Kalden, C. Antoni, F. C. Breedveld, J. S. Smolen, G. Eberl, K. deWoody, M. Feldmann, R. N. Maini, Regulation of cytokines, cytokine inhibitors, and acute-phase proteins following anti-TNF-alpha therapy in rheumatoid arthritis. J Immunol 163, 1521-1528 (1999).

59. F. M. Brennan, D. Chantry, A. Jackson, R. Maini, M. Feldmann, Inhibitory effect of TNF alpha antibodies on synovial cell interleukin-1 production in rheumatoid arthritis. Lancet 2, 244-247 (1989).

60. M. J. Elliott, R. N. Maini, M. Feldmann, A. Long-Fox, P. Charles, P. Katsikis, F. M. Brennan, J. Walker, H. Bijl, J. Ghrayeb, et al., Treatment of rheumatoid arthritis with chimeric monoclonal antibodies to tumor necrosis factor alpha. Arthritis Rheum 36, 1681-1690 (1993).

61. F. Ingegnoli, F. Fantini, E. G. Favalli, A. Soldi, S. Griffini, V. Galbiati, P. L. Meroni, M. Cugno, Inflammatory and prothrombotic biomarkers in patients with rheumatoid arthritis: effects of tumor necrosis factor-alpha blockade. J Autoimmun 31, 175-179 (2008).

62. B. R. Thomson, S. Heinen, M. Jeansson, A. K. Ghosh, A. Fatima, H. K. Sung, T. Onay, H. Chen, S. Yamaguchi, A. N. Economides, A. Flenniken, N. W. Gale, Y. K. Hong, A. Fawzi, X. Liu, T. Kume, S. E. Quaggin, A lymphatic defect causes ocular hypertension and glaucoma in mice. J Clin Invest 124, 4320-4324 (2014).

63. M. E. Pitulescu, I. Schmidt, R. Benedito, R. H. Adams, Inducible gene targeting in the neonatal vasculature and analysis of retinal angiogenesis in mice. Nat Protoc 5, 15181534 (2010). 
medRxiv preprint doi: https://doi.org/10.1101/2021.01.13.21249429; this version posted May 27, 2021. The copyright holder for this preprint (which was not certified by peer review) is the author/funder, who has granted medRxiv a license to display the preprint in perpetuity.

\section{FIGURE 1}
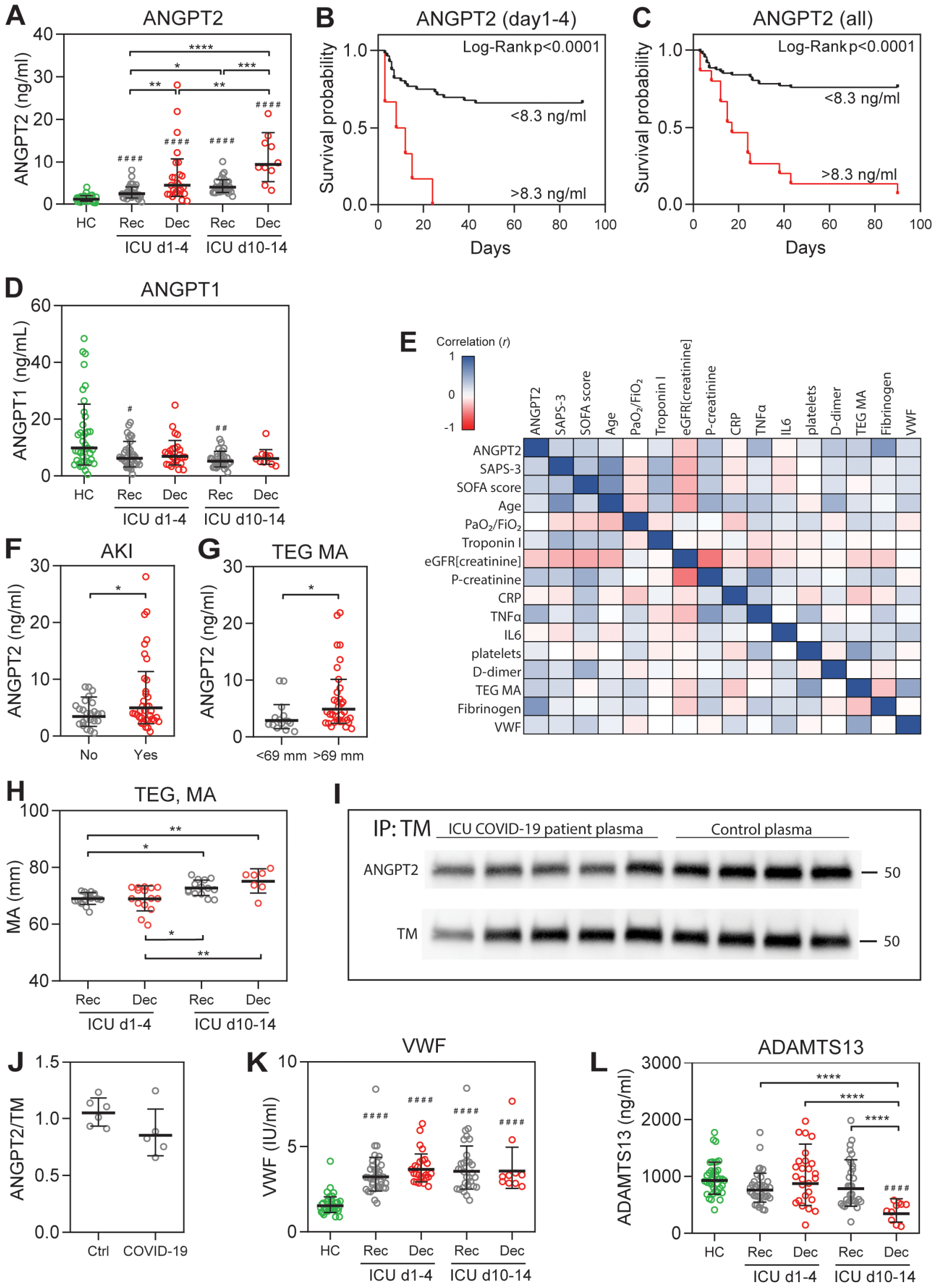
medRxiv preprint doi: https://doi.org/10.1101/2021.01.13.21249429; this version posted May 27, 2021. The copyright holder for this preprint (which was not certified by peer review) is the author/funder, who has granted medRxiv a license to display the preprint in perpetuity.

\section{Figure 1. Plasma ANGPT2 is increased in critically ill COVID-19 patients and correlates} to mortality and hypercoagulation

(A) Plasma ANGPT2 concentrations for healthy controls (HC), recovered (Rec) and deceased (Dec) patients at day 1-4 and day 10-14 after admission. (B, C) Kaplan Meier plots with Logrank test show that ANGPT2 levels are higher in non-recovering patients both at admission and when including all time-points and can predict mortality. (D) Plasma ANGPT1 was minimally affected. (E) Clinical data and measured parameters were analyzed by Pearson correlation test (Spearman for SAPS-2 and SOFA score) and presented in a heatmap for correlation (blue) or inverse correlation (red). A summary of ANGPT2 comparisons is presented in Table 3, and all data in Suppl. Table 1. (F) ANGPT2 is higher in patients with acute kidney injury (AKI) compared to non-AKI patients. (G) ANGPT2 is higher in patients with MA $>69$. $(\mathrm{H})$ Thromboelastography (TEG) measurements for MA, other TEG measurements can be seen in Table 2. (I, J) Immunoprecipitation and quantification of thrombomodulin (TM) from plasma in controls and COVID-19 patients show binding of ANGPT2. Full uncut blots available in Suppl Fig 1. (K, L) Plasma concentrations for VWF and ADAMTS13, respectively.

Data shown as shown as geometric mean $\pm 95 \%$ CI (A, D, F-H, J-L). \#\#\# $\mathrm{p}<0.0001$ vs. HC, ${ }^{*} \mathrm{p}<0.05, \quad{ }^{* *} \mathrm{p}<0.01, \quad * * * \mathrm{p}<0.001, * * * * \mathrm{p}<0.0001$. $\mathrm{p}$-value from one-way ANOVA with Bonferroni post hoc test (A, D, H, K, L), and t-test (F, G, J) on log transformed data. TEG thromboelastography; $M A$ maximal amplitude 


\section{FIGURE 2}
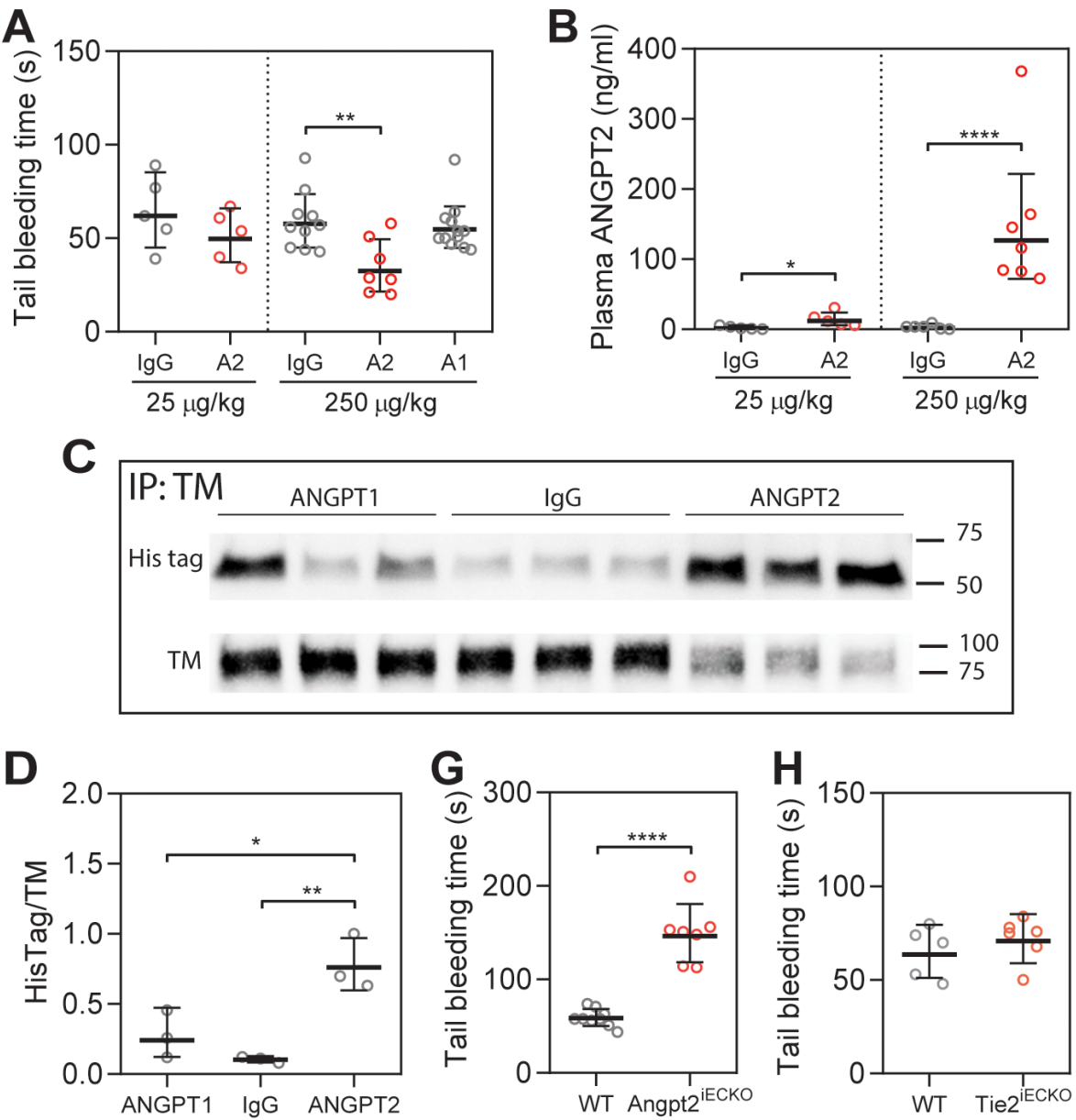

Figure 2. ANGPT2 bind thrombomodulin and shortens tail bleeding time in mice

(A) Tail bleeding time 15 min after i.p. injection of His tagged ANGPT2 (A2), and ANGPT1 (A1) at indicated doses. Albumin or IgG was injected in controls. (B) Plasma concentrations of ANGPT2 after i.p injection. (C, D) Immunoprecipitation and quantification of thrombomodulin (TM) from lung lysates in injected mice with blotting for His tag and TM. (G, H) Tail bleeding time in Angpt $2^{\mathrm{iECKO}}$ mice and Tie $2^{\mathrm{iECKO}}$ mice, respectively. Data presented as geometric mean $\pm 95 \%$ CI. ${ }^{*} \mathrm{p}<0.05, * * \mathrm{p}<0.01, * * * * \mathrm{p}<0.0001 . \mathrm{p}$-value from one-way ANOVA with Bonferroni post hoc test $(A, B, D)$, and t-test $(\mathrm{G}, \mathrm{H})$ on $\log$ transformed data. 


\section{FIGURE 3}

A

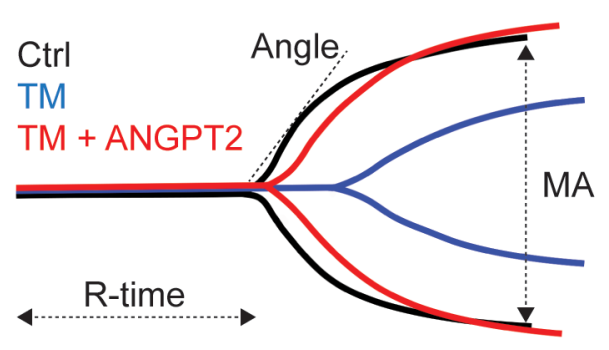

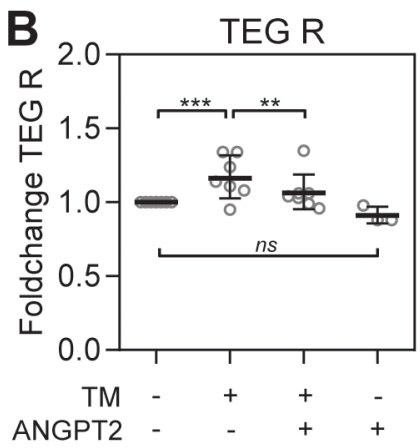

D

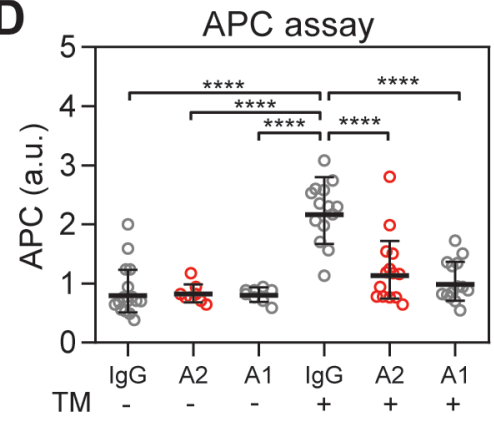

Figure 3. ANGPT2 inhibits thrombomodulin mediated anticoagulation and protein C activation

TEG curve from one of the donors showing thrombomodulin (TM) dependent increase in reaction time (R) and decreased maximal amplitude (MA), which is inhibited by ANGPT2 (A). TEG analysis of individual donor blood with addition of $1000 \mathrm{ng} / \mathrm{ml}$ thrombomodulin (TM) and $1000 \mathrm{ng} / \mathrm{ml}$ ANGPT2. Foldchange graphs from TEG analysis for R (B) and MA (C). Group results from these experiments can be found in Table 4. Thrombomodulin dependent formation of APC can be inhibited with ANGPT2 or ANGPT1 (D). Data presented as geometric mean \pm $95 \%$ CI. $* * \mathrm{p}<0.01, * * * \mathrm{p}<0.001, * * * * \mathrm{p}<0.0001$. p-value from one-way ANOVA with Bonferroni post hoc test on log transformed data. TEG thromboelastography 
medRxiv preprint doi: https://doi.org/10.1101/2021.01.13.21249429; this version posted May 27, 2021. The copyright holder for this preprint (which was not certified by peer review) is the author/funder, who has granted medRxiv a license to display the preprint in perpetuity. It is made available under a CC-BY-NC-ND 4.0 International license .

\section{FIGURE 4}

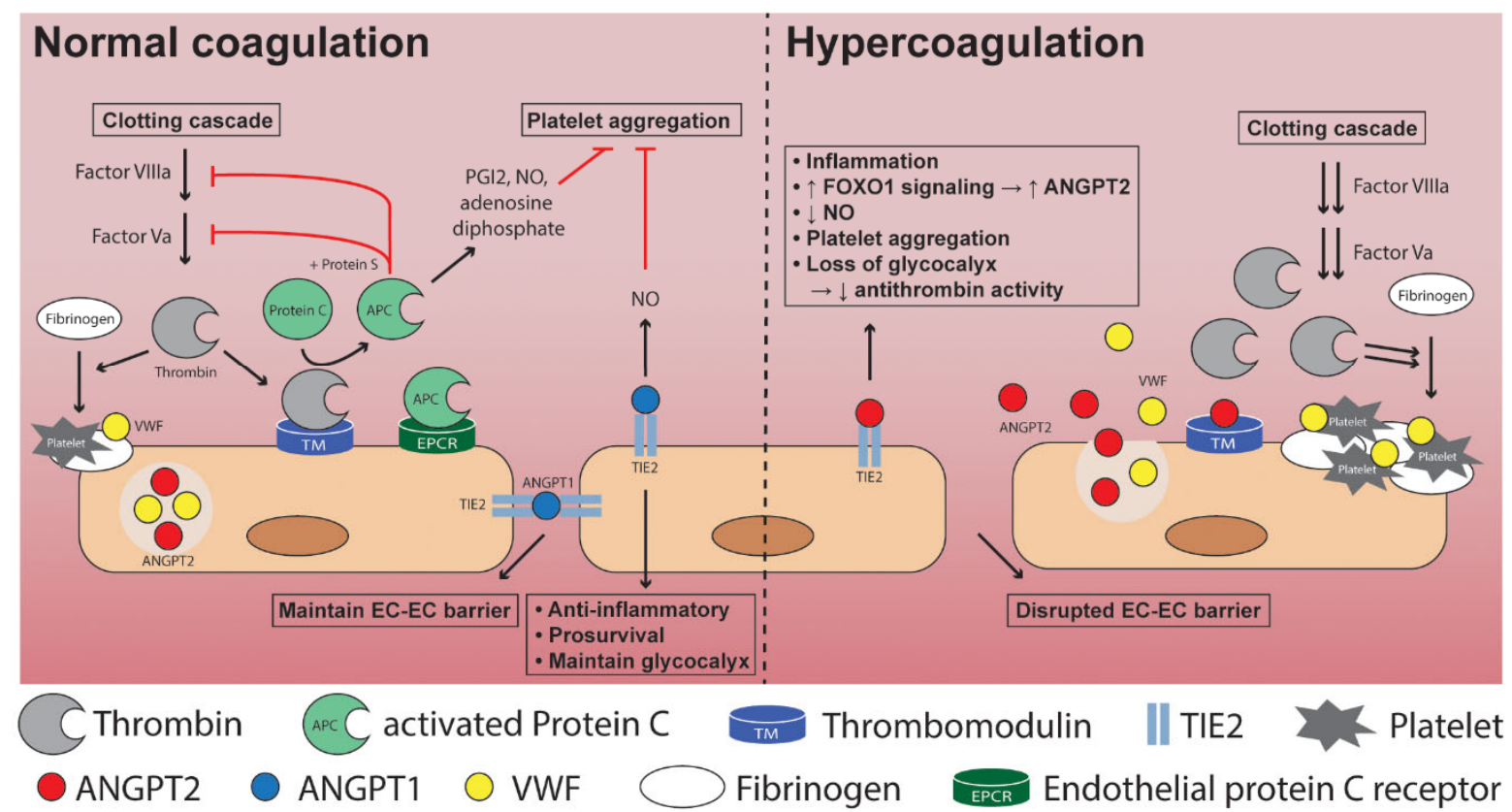

Figure 4. A schematic overview of Angiopoietin signaling in normal coagulation and in hypercoagulation with high ANGPT2. In addition to ANGPT2 inhibition of thrombomodulin mediated anticoagulation several other endothelial functions are disturbed by high ANGPT2. 
medRxiv preprint doi: https://doi.org/10.1101/2021.01.13.21249429; this version posted May 27, 2021. The copyright holder for this preprint

(which was not certified by peer review) is the author/funder, who has granted medRxiv a license to display the preprint in perpetuity.

It is made available under a CC-BY-NC-ND 4.0 International license .

Table 1. Patient demographic characteristic and comorbidities

\begin{tabular}{|c|c|}
\hline & $\begin{array}{l}\text { All patients } \\
\qquad(\mathrm{n}=61)\end{array}$ \\
\hline Women, n (\%) & $12(20)$ \\
\hline Age, years & $60.9(56.7-65.4)$ \\
\hline Body weight, kg & $88.6(83.5-93.9)$ \\
\hline $\mathrm{BMI}, \mathrm{kg} / \mathrm{m}^{2}$ & $30.1(28.5-31.8)$ \\
\hline COVID-19 day on ICU arrival & $9.2(8.3-10.3)$ \\
\hline Invasive ventilation & $49(80)$ \\
\hline 90-day mortality & $36(59)$ \\
\hline \multicolumn{2}{|l|}{ Comorbidities, n (\%) } \\
\hline Pulmonary disease & $18(30)$ \\
\hline Hypertension & $38(62)$ \\
\hline Heart failure & $4(7)$ \\
\hline Peripheral vessel disease & $17(28)$ \\
\hline Previous thromboembolic event & $8(13)$ \\
\hline Diabetes & $21(34)$ \\
\hline Malignancy & $6(10)$ \\
\hline$\geq 2$ risk factors & $32(26)$ \\
\hline \multicolumn{2}{|l|}{ Clinical features at arrival } \\
\hline ARDS, n (\%) & $20(100)$ \\
\hline SAPS3 score & $53(51-56)$ \\
\hline
\end{tabular}


medRxiv preprint doi: https://doi.org/10.1101/2021.01.13.21249429; this version posted May 27, 2021. The copyright holder for this preprint (which was not certified by peer review) is the author/funder, who has granted medRxiv a license to display the preprint in perpetuity. It is made available under a CC-BY-NC-ND 4.0 International license.

Table 2. Clinical parameters of patients during ICU stay.

\begin{tabular}{|c|c|c|c|c|c|c|c|}
\hline & Day 1-4 & $\mathbf{n}$ & Day 10-14 & $\mathbf{n}$ & p-value ${ }^{A}$ & $\begin{array}{c}\text { Reference } \\
\text { range }\end{array}$ & p-value ${ }^{\mathrm{B}}$ \\
\hline ANGPT2 $(\mathrm{ng} / \mathrm{ml})$ & $3.1(2.6-3.8)$ & 61 & $4.8(4.0-5.8)$ & 40 & $* *$ & $1.2(1.9-1.4)^{C}$ & $* * * *$ \\
\hline ANGPT1 (ng/ml) & $6.2(4.9-7.8)$ & 61 & $5.2(4.4-6.3)$ & 40 & ns & $9.9(7.3-13.4)^{c}$ & ns \\
\hline VWF (IU/ml) & $3.4(3.2-3.7)$ & 61 & $3.6(3.2-4.0)$ & 40 & ns & $1.5(1.4-1.7)^{C}$ & $* * * *$ \\
\hline ADAMTS13 $(\mathrm{ng} / \mathrm{ml})$ & 887 (789-996) & 61 & $640(524-782)$ & 40 & $* *$ & $930(844-1025)^{C}$ & ns \\
\hline Platelets $\left(\times 10^{9} / \mathrm{I}\right)$ & $231(208-258)$ & 58 & $426(353-514)$ & 37 & $* * * *$ & $150-300$ & ns \\
\hline D-dimer (mg/l) & $2.27(1.70-3.03)$ & 60 & $2.49(1.85-3.35)$ & 34 & ns & $<0.50$ & $* * * *$ \\
\hline CRP (mg/l) & 192 (164-224) & 59 & 65 (45-95) & 38 & $* * * *$ & $<5$ & $* * * *$ \\
\hline SOFA score & $6(6-7)$ & 60 & $6(5-7)$ & 40 & ns & 0 & $* * * *$ \\
\hline $\mathrm{PaO}_{2} / \mathrm{FiO}_{2}$ & $18.6(17.0-20.3)$ & 57 & $23.2(20.9-25.7)$ & 37 & $* *$ & $>60$ & $* * * *$ \\
\hline Ferritin $(\mu \mathrm{g} / \mathrm{l})$ & 1377 (1033-1837) & 56 & 1417 (979-2068) & 36 & ns & $25-310$ & $* * * *$ \\
\hline Lactate (mmol/l) & $1.3(1.2-1.4)$ & 59 & $1.2(1.1-1.4)$ & 38 & ns & $0.8-2.0$ & ns \\
\hline TNFa (ng/l) & 66.7 (56.4-79.0) & 40 & & & & $<8.0$ & $* * * *$ \\
\hline IL6 (ng/l) & 156 (120-204) & 35 & & & & $<7.0$ & $* * * *$ \\
\hline Fibrinogen $(\mathrm{g} / \mathrm{l})$ & $8.4(7.6-9.3)$ & 15 & & & & $2.0-4.2$ & $* * * *$ \\
\hline \multicolumn{8}{|l|}{ TEG } \\
\hline $\mathrm{R}(\min )$ & $8.7(7.5-10.0)$ & 30 & $12.3(8.6-17.5)$ & 22 & ns & 4.6-9.1 & ns \\
\hline $\mathrm{R}_{\mathrm{KCH}}(\min )$ & $7.3(6.8-8.0)$ & 30 & $9.2(8.0-10.6)$ & 22 & $* *$ & $4.3-8.3$ & ns \\
\hline Angle (deg) & $77.1(75.8-78.4)$ & 30 & 76.5 (74.2-78.9) & 22 & ns & $64-77$ & ns \\
\hline $\mathrm{MA}(\mathrm{mm})$ & $68.8(67.2-70.4)$ & 30 & $73.6(72.1-75.1)$ & 22 & $* * * *$ & $52-69$ & ns \\
\hline
\end{tabular}

Data are expressed as geometric mean $\pm 95 \% \mathrm{Cl}$. CRP C-reactive protein; PaO2/FiO2 the ratio of arterial oxygen partial pressure ( $\mathrm{PaO} 2$ in $\mathrm{mmHg}$ ) to fractional inspired oxygen; TEG thromboelastography, $\mathrm{R}$ reaction time; $\mathrm{KCH}$ kaolin with heparinase; MA maximum amplitude.

Ap-values from unpaired t-test on log transformed data comparing patients at day 1-4 and patients at day 10-14. ${ }^{B} \mathrm{p}$-values from Fisher's exact test comparing patients at day 1-4 with reference range.

${ }^{C}$ measured in healthy controls in the study. 
medRxiv preprint doi: https://doi.org/10.1101/2021.01.13.21249429; this version posted May 27, 2021. The copyright holder for this preprint (which was not certified by peer review) is the author/funder, who has granted medRxiv a license to display the preprint in perpetuity. It is made available under a CC-BY-NC-ND 4.0 International license.

Table 3. Correlation of ANGPT2 and other parameters in the cohort.

\begin{tabular}{lccc} 
ANGPT2 vs. & $\mathbf{r}$ & $\mathbf{p}$ & $\mathbf{n}$ \\
\hline SAPS-3 & 0.270 & $*$ & 58 \\
SOFA score & 0.286 & $* *$ & 100 \\
Age & 0.183 & $n s$ & 61 \\
$\mathrm{PaO}_{2} / \mathrm{FiO}_{2}$ & -0.007 & $\mathrm{~ns}$ & 94 \\
$\mathrm{eGFR}^{[\text {[creat] }}$ & -0.352 & $* * * *$ & 97 \\
Troponin I & 0.152 & $\mathrm{~ns}$ & 94 \\
$\mathrm{CRP}$ & -0.078 & $\mathrm{~ns}$ & 95 \\
TNFa & 0.442 & $* *$ & 40 \\
II6 & -0.063 & $\mathrm{~ns}$ & 41 \\
Platelet count & 0.118 & $\mathrm{~ns}$ & 95 \\
D-dimer & 0.330 & $*$ & 94 \\
Fibrinogen & 0.609 & $*$ & 15 \\
TEG MA & 0.287 & $*$ & 49 \\
VWF & 0.200 & $*$ & 101 \\
\hline p-value from Pearson's correlation test for all parameters except \\
SAPS-3, SOFA score, and TEG MA where Spearman's correlation test \\
was used.
\end{tabular}

Table 4. TEG data from in vitro experiments

\begin{tabular}{|c|c|c|c|c|}
\hline & Control & TM & TM+ANGPT2 & ANGPT2 \\
\hline $\mathrm{R}(\min )$ & $8.5(6.8-10.6)$ & $10.0(7.4-13.6)^{*}$ & $9.2(7.0-11.9)$ & $8.0(3.8-16.6)$ \\
\hline Angle (deg) & $65.3(60.7-70.1)$ & $54.6(42.1-70.9)$ & 59.5 (50.7-69.7) & 67.8 (59.4-77.4) \\
\hline $\mathrm{MA}(\mathrm{mm})$ & $44.8(36.3-55.2)$ & $39.5(28.2-55.2)$ & $43.5(34.2-55.3)$ & $45.3(24.8-82.8)$ \\
\hline
\end{tabular}




\section{SUPPL. FIGURE 1}
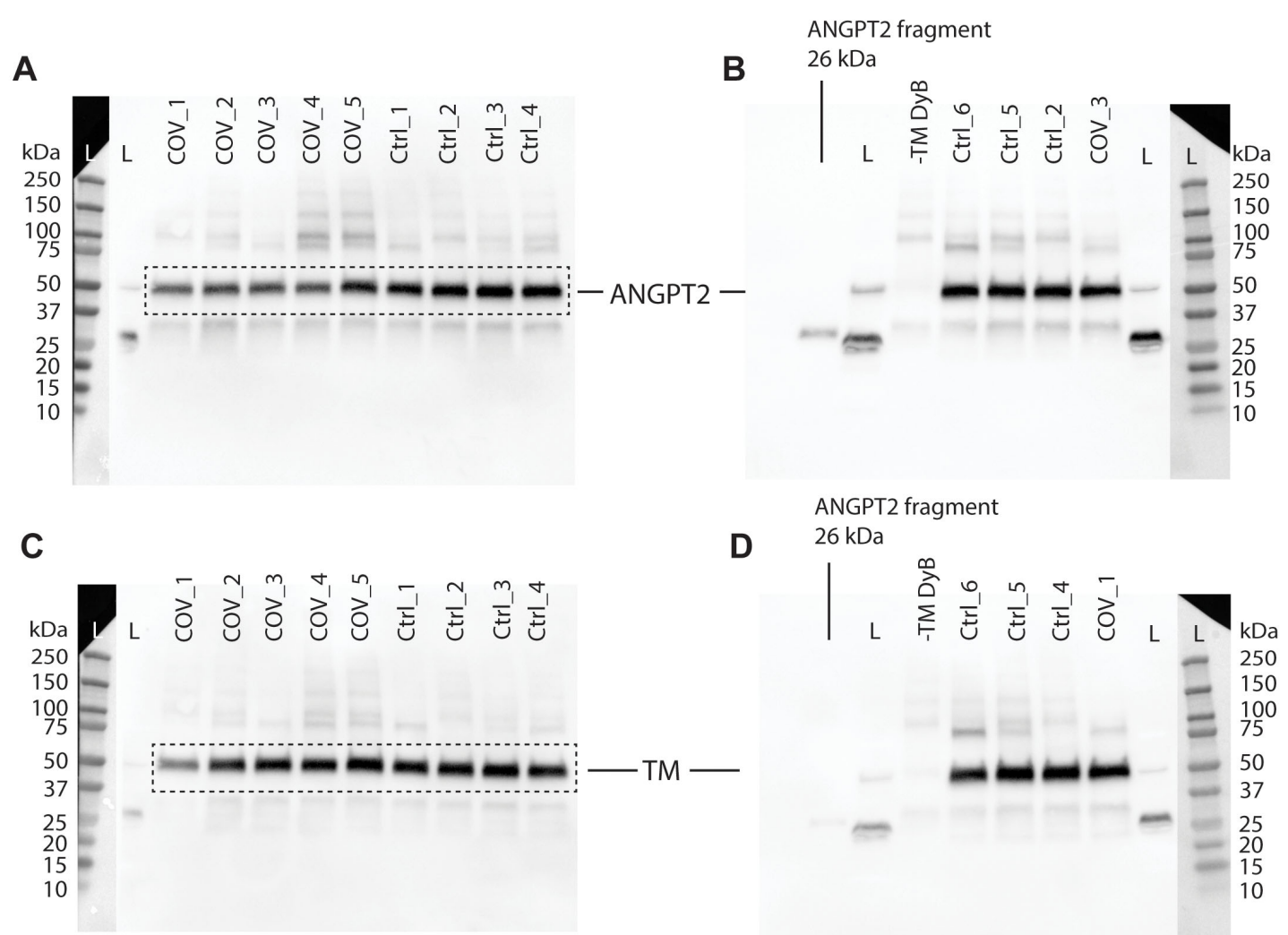

$26 \mathrm{kDa}$

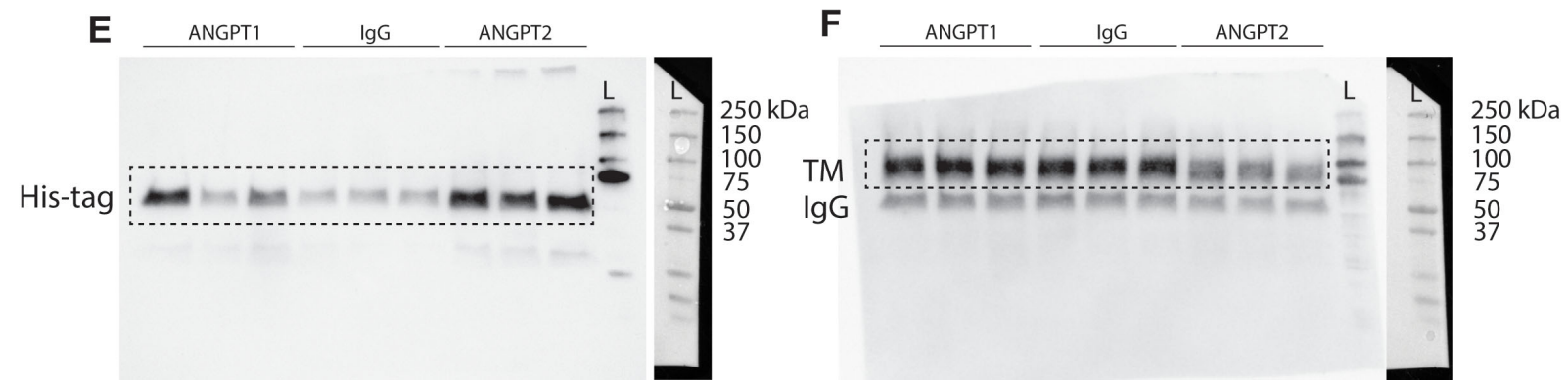

Suppl. Figure 1. Uncut blot images.

(A, B) Blots for ANGPT2 used for quantification in Fig. 1J, the dashed line marks the cut-out for Fig. 1I. (C, D) Blots for thrombomodulin used for quantification in Fig. 1J, the dashed line marks the cut-out for Fig. 1I. The pasted ladder (far left in A, C; far right in B, D) is the calorimetric signal for the ladder (L) in the blot. (E, F) Blots for His-tag (ANGPT2) and thrombomodulin, respectively, used for quantification in Fig. 2D, the dashed line marks the cutout for Fig. 2C. The pasted ladder (far left in E, F) is the calorimetric signal for the ladder (L) in the blot. 
medRxiv preprint doi: https://doi.org/10.1101/2021.01.13.21249429; this version posted May 27, 2021. The copyright holder for this preprint (which was not certified by peer review) is the author/funder, who has granted medRxiv a license to display the preprint in perpetuity.

Suppl. Table 1. Correlations between various parameters within the cohort

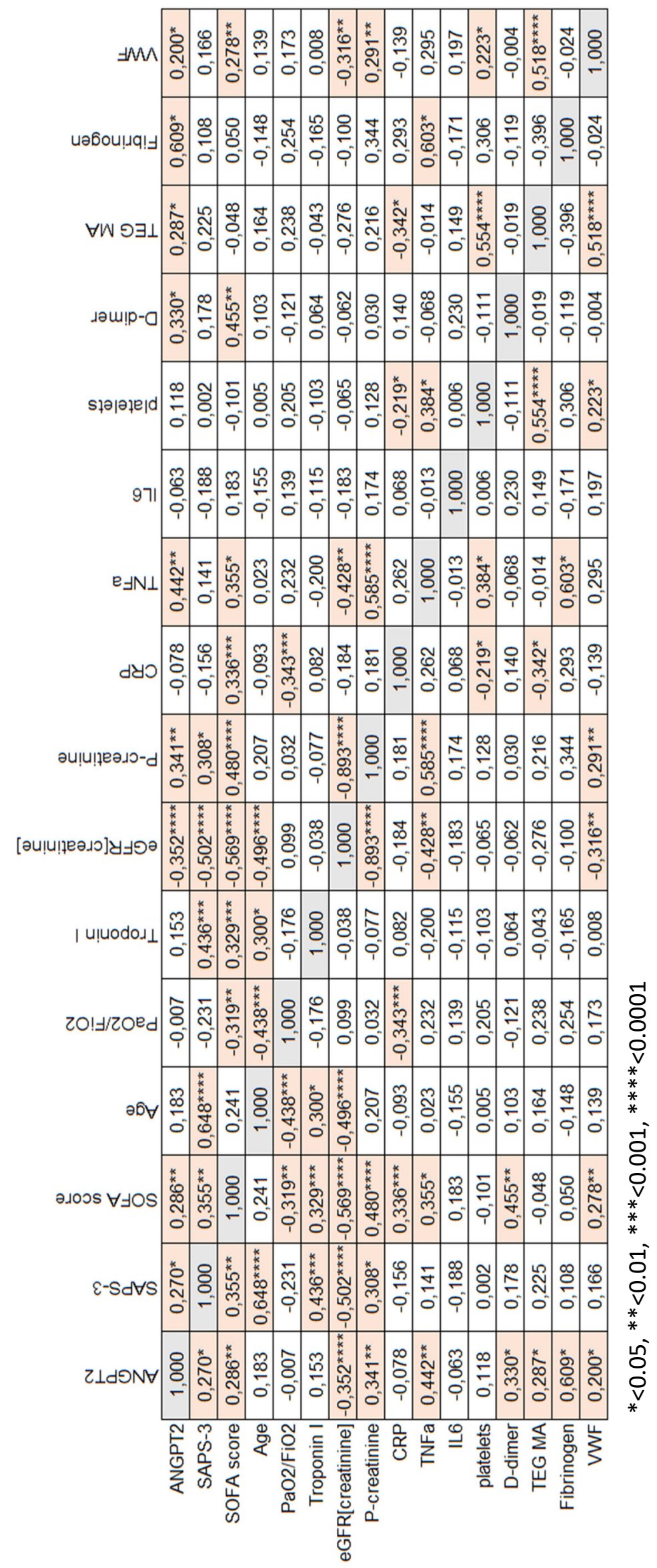

